\title{
Pelatihan Pembuatan Sabun Cair Sebagai Peluang Wirausaha Rumah Tangga di Kota Pekanbaru
}

\author{
Ainun Mardiah*1, Rozalinda ${ }^{2}$, Ratna Dewi ${ }^{3}$, Sehani ${ }^{4}$, Desvi Emti ${ }^{5}$, Herlinda $^{6}$ \\ 1,2,4,5Program Studi Manajemen, Fakultas Ekonomi dan Ilmu Sosial, Universitas Islam Negeri Sultan Syarif \\ Kasim Riau \\ ${ }^{3}$ Program Studi Administrasi Negara, Fakultas Ekonomi dan Ilmu Sosial, Universitas Islam Negeri Sultan \\ Syarif Kasim Riau \\ 5Program Studi Pendidikan Bahasa Indonesia, Fakultas Tarbiyah dan Keguruan, Universitas Islam Negeri \\ Sultan Syarif Kasim Riau \\ *e-mail: ainun.mardiah@uin-suska.ac.id
}

\begin{abstract}
This community service activity aims to provide knowledge to the community about the production process of making liquid soap that can be used as an entrepreneurial opportunity for the community in Pekanbaru City. This activity was held in Tangkerang Barat Village, Pekanbaru City on October 2, 2019. The training participants were housewives and the taklim assembly in Tangkerang Barat Village with a total of 15 training participants. The method of community service activities uses lecture and demonstration methods about making dish soap liquid soap. The evaluation design for service activities is the achievement of the target number of training participants, the training objectives are well achieved, the planned material targets are achieved and the participants are able to understand the training material. The result of this service activity is that the participants understand the entrepreneurial opportunities of making dishwashing liquid soap, then the training participants can make dishwashing liquid soap and there are already training participants who have succeeded in selling the liquid soap product.
\end{abstract}

Keywords: Training, dish soap

\begin{abstract}
Abstrak
Kegiatan pengabdian kepada masyarakat ini bertujuan untuk memberikan pengetahuan kepada masyarakat mengenai proses produsi pembuatan sabun cair yang dapat digunakan sebagai peluang wirausaha bagi masyarakat di Kota Pekanbaru. Kegiatan ini dilaksanakan di Kelurahan Tangkerang Barat, Kota Pekanbaru pada tanggal 02 Oktober 2019. Peserta pelatihan adalah ibu rumah tangga dan majelis taklim di Kelurahan Tangkerang Barat dengan jumlah peserta sebanyak 15 peserta pelatihan. Metode kegiatan pengabdian masyarakat menggunakan metode ceramah dan demonstrasi tentang pembuatan sabun cair sabun cuci piring. Rancangan evaluasi kegiatan pengabdian adalah tercapainya target jumlah peserta pelatihan, tujuan pelatihan tercapai dengan baik, target materi yang direncanakan tercapai dan para peserta mampu memahami materi pelatihan. Hasil kegiatan pengabdian ini adalah para peserta memahami akan peluang wirausaha pembuatan sabun cair cuci piring, kemudian peserta pelatihan dapat membuat sabun cair cuci piring dan peserta pelatihan sudah ada yang berhasil menjual produk sabun cair tersebut.
\end{abstract}

Kata kunci: Pelatihan, sabun cuci piring

\section{PENDAHULUAN}

Keberdayaan perempuan di bidang ekonomi adalah salah satu indikator meningkatnya kesejahteraan. Saat perempuan menjadi kaum terdidik, mempunyai hak-hak kepemilikan, dan bebas untuk bekerja di luar rumah serta mempunyai pendapatan mandiri, inilah tanda kesejahteraan rumah tangga meningkat. Lebih dari itu, perempuan juga mempunyai andil besar dalam kegiatan penanggulangan kemiskinan melalui pemberdayaan masyarakat dan kelompok. Salah satu buktinya, bahwa perempuan dapat meningkatkan kesejahteraan keluarganya dengan melakukan kegiatan usaha produktif rumah tangga.

Menurut Moh. Ali Aziz (2005), Pemberdayaan masyarakat merupakan suatu proses di mana masyarakat, khususnya mereka yang kurang memiliki akses ke sumber daya pembangunan, didorong untuk meningkatkan kemandiriannya di dalam mengembangkan 
perikehidupan mereka. Pemberdayaan masyarakat juga merupakan proses siklus terusmenerus, proses partisipatif di mana anggota masyarakat bekerja sama dalam kelompok formal maupun informal untuk berbagi pengetahuan dan pengalaman serta berusaha mencapai tujuan bersama. Jadi, pemberdayaan masyarakat lebih merupakan suatu proses". (planner). Sebagai penemu wirausaha menemukan dan menciptakan produk baru, teknologi dan cara baru, ide-ide baru, dan organisasi baru. Sedangkan sebagai perencana, wirausaha berperan merancang usaha baru, merencanakan strategi perusahaan baru, merencanakan ide-ide dan peluang dalam perusahaan, dan menciptakan organisasi perusahaan baru.

Wirausaha adalah seseorang yang memiliki kemampuan dalam menggunakan dan mengkombinasikan sumber daya seperti keuangan, material, tenaga kerja, keterampilan untuk menghasilkan produk, proses produksi, bisnis dan orgasisasi usaha baru (Longenecker, Moore dan Patty, 2001). Robbins dan Mary Coulter (2010) adalah proses di mana seseorang atau sekelompok orang menggunakan usaha dan sarana yang terorganisasi untuk mengejar peluang guna menciptakan nilai dan bertumbuh dengan memenuhi keinginan dan kebutuhan melalui inovasi dan keunikan.

Pemberdayaan ibu rumah tangga sebagai anggota masyarakat dan masih tergolong sebagai tenaga kerja produktif sangat penting dilakukan, bertujuan untuk menumbuhkan kesadaran dan kemandirian dalam berusaha, sekaligus memperluas lapangan kerja guna meningkatkan pendapatan keluarga dalam usaha mencapai keluarga yang bahagia dan sejahtera. Dalam kaitannya dengan upaya untuk membina dan mengembangkan potensi keluarga dan daerah, dapat dilakukan melalui berbagai alternatif kegiatan, diantaranya berupa pelatihan pembuatan sabun dan deterjen.

Menurut Andrew E. Sikula dalam Hasibuan (2009) pelatihan adalah suatu proses pendidikan jangka pendek dengan menggunakan prosedur yang sistematis dan terorganisir sehingga karyawan operasional belajar pengetahuan teknik pengerjaan dan keahlian untuk tujuan tertentu. Organisasi atau perusahaan di abad ini dituntut untuk mempunyai keunggulan bersaing dalam hal kualitas produk, service, biaya maupun sumber daya manusia yang profesional. Jenis-jenis pelatihan yang digunakan dalam organisasi (Simamora, 2004) adalah pelatihan keahlian-keahlian (skill training), pelatihan ulang (retraining), pelatihan fungsional silang (cross functional training), pelatihan tim (team training, pelatihan kreativitas (creativity training).

Sabun dan deterjen merupakan sebuah komoditas yang tidak bisa dilepaskan dari kebutuhan rumah tangga dewasa ini. Memang tidak bisa dipungkiri bahwa intensitas pemakaian sabun dalam kehidupan sehari-hari terbilang rutin dikonsumsi. Hal ini dikarenakan fungsi utama dari sabun yang bersifat membersihkan atau mengangkat kotoran yang menempel pada sebuah permukaan. Oleh karena itu, dapat dikatakan bahwa pengeluaran rutin bagi ibu rumah tangga tiap bulannya sebagian dialokasikan untuk pembelian sabun cuci.

Seiring perkembangan teknologi dan perubahan zaman, banyak sekali bentuk dan jenis sabun yang ditawarkan kepada konsumen di pasar mulai dari sabun cuci (krim dan bubuk), sabun mandi (padat dan cair), sabun tangan (cair) serta sabun pembersih peralatan rumah tangga dan dapur (krim dan cair). Umumnya dikalangan ibu rumah tangga, pengeluaran konsumsi sabun yang terbilang sering adalah sabun cuci piring. Produk Pencuci piring pada prinsipnya terbagi ke dalam tiga jenis yang berdasarkan atas penampilan fisiknya. Pertama adalah sabun bubuk atau serbuk, kedua sabun pasta atau krim, dan ketiga berbentuk cairan.

Sabun cuci bubuk sepertinya kurang dikenal oleh masyarakat, meskipun pernah dijual di swalayan. Produk kedua, sabun pasta/krim atau yang lebih dikenal dengan sabun colek terbilang produk pencuci piring yang sering dibeli konsumen di pasaran. Dan produk ketiga pencuci piring berbentuk cairan kental, dimana produk ini yang paling banyak dibeli dan dikonsumsi oleh konsumen dikalangan ibu rumah tangga. Dari tiga jenis produk pencuci piring 
yang ditawarkan kepada konsumen, dapat dikatakan bahwa kecenderungan pemakaian sabun cuci cair dari waktu ke waktu mengalami peningkatan yang cukup pesat.

Peningkatan konsumsi sabun cuci cair ini dapat dipahami bahwa kebiasaan/pola pencucian piring para ibu rumah tangga (termasuk alat rumah tangga lainnya) sudah mulai bergeser, dimana pergeseran itu terlihat konsumen sudah pelan-pelan meninggalkan cara tradisional yang menggunakan abu gosok dan sabun colek menuju cara baru yang lebih praktis. Kehadiran sabun cuci cair ini memberikan kepraktisan dalam penggunaan untuk membersihkan peralatan makan seperti piring, gelas, sendok/garpu dan peralatan dapur pada umumnya. Selain itu, kecepatan sabun cair dapat larut baik didalam air dan aroma produk yang khas menjadikan cairan pencuci piring mempunyai nilai lebih dibanding produk pencuci piring lainnya seperti sabun cuci krim yang memberikan efek kurang lembut ditangan dan meninggalkan aroma sabun krim pada peralatan dapur. Faktor keuntungan lainnya bila menggunakan sabun cuci cair ini bila ditinjau dari sisi kesehatan tergolong lebih higienis.

Oleh karena itu, kebutuhan akan produk sabun cair semakin lama semakin meningkat. Maka banyak sekali produk-produk sabun cair yang bisa ditemukan pada berbagai jenis pasar. Pada prinsipnya dalam pembuatan sabun cair ini tidak memerlukan bahan dan peralatan yang rumit. Untuk proses produksinya tidak serumit bila dibandingkan dengan pembuatan sabun pembersih lainnya (pastaatau powder). Selama ini sebagian masyarakat menganggap pembuatan sabun cuci cair sulit, padahal bahan-bahan bakunya mudah didapatkan pada tokotoko bahan kimia dengan harganya yang terjangkau.

Melalui kegiatan pengabdian pada masyarakat ini diharapkan dapat memberikan keterampilan dan pengetahuan kepada masyarakat khususnya ibu rumah tangga di Kelurahan Tangkerang Barat, tentang pembuatan sabun cuci cair sederhana dan berbahan yang ramah lingkungan. Dengan adanya pelatihan ini, diharapkan dapat melengkapi wawasan pengetahuan dan keterampilan ibu-ibu rumah tangga dalam berbagai segi kehidupan keluarga, yang dapat digunakan untuk menunjukkan eksistensi dirinya, turut memenuhi kebutuhan keluarganya sehingga dengan melakukan sendiri akan menghemat keuangan keluarga dan dapat dijadikan bekal untuk membuka usaha yang pada akhirnya dapat menambah penghasilan keluarga.

\section{METODE}

Dalam pelaksanaan pengabdian kepada masyarakat ini ada beberapa metode atau bentuk kegiatan yang akan dilaksanakan serta sesuai untuk memecahkan berbagai permasalahan dalam kegiatan pengabdian antara lain adalah metode ceramah, demonstrasi dan praktek. Tujuan metode praktek adalah menambah wawasan tentang informasi serta melatih pola pikir peserta untuk dapat menggali permasalahan, yang kemudian akan dianalisa dan dicari penyelesaiannya secara integral komprehensif. Pada metode ini kami selaku tim pengabdian masyarakat memperagakan proses pembuatan sabun cair untuk cuci piring.

Dalam pengabdian masyarakat ini khalayak sasaran yang dianggap strategis untuk dapat dilibatkan dalam kegiatan pengabdian masyarakat ini adalah masyarakat di Kota Pekanbaru. Pelatihan ini diikuti oleh ibu rumah tangga dan majelis taklim di Kelurahan Tangkerang Barat, Kota Pekanbaru. Jumlah peserta pelatihan ini adalah 15 orang. Kegiatan pelatihan ini diadakan Kantor Lurah Tangkerang Barat, Kota Pekanbaru dan dilaksanakan selama 1 hari. Tim pengabdi dalam kegiatan pengabdian ini adalah dosen Fakulas Ekonomi dan Ilmu Sosial UIN Suska Riau.

\section{HASIL DAN PEMBAHASAN}

Adapaun bahan- bahan yang diperlukan dalam pembuatan sabun cuci piring adalah:

1. Texapon. Texapon adalah bahan kimia yang mempunyai fungsi salah satunya mengankat lemak dan kotoran atau zat yang memiliki sifat surfaktan. texapon sudah sangat di kenal 
dalam industri pembuatan bahan untuk kebersihan seperti cairan pencuci piring, cairan pencuci tangan, shampoo dan lain sebagainya. Texapon adalah surfaktan buatan yang dapat digunakan sebagai bahan dasar pembuatan sabun cair, sampo, dan pasta gigi. Texapon disebut juga sodium laurilsulfate (C12H25SO4Na). Bahan baku texapon yang berasal dari turunan minyak kelapa. Kelebihannya adalah mudah diurai kembali oleh alam, mudah ditoleransi oleh tubuh, dan daya bersih cukup baik walau tidak sekuat yang berbahan ABS dan LAS. bahan baku texapon (SLES), yang berasal dari turunan minyak kelapa. Kelebihannya adalah mudah diurai kembali oleh alam, mudah ditoleransi oleh tubuh, dan daya bersih cukup baik walau tidak sekuat yang berbahan ABS dan LAS.

2. SLS adalah jenis surfaktan yang sangat kuat dan umum digunakan dalam produk-produk pembersih noda minyak dan kotoran. Garam kimia ini adalah gugus sulfat, membuat zat kimia ini mempunyai sifat ambifilikyang merupakan organosulfur anion yang mengandung 12-ekor karbon terikat ke syarat sebagai deterjen. SLS/ texapon juga dikelaskan kosentrasinya kepada beberapa jenis produk seperti $\mathrm{N} 70$ berarti kosentrasi SLS nya cuma $70 \%$,

3. Sodium Sulfat. Merupakan garam berwujud padatan atau kristal berwarna putih. Sodium sulfat tidak berwarna dan stabil pada temperatur normal. Fungsi Sodium sebagai pengental dan penambah busa juga untuk membantu melarutkan texapon.

4. Natrium Chlorida. Natrium Klorida atau garam adalah senyawa yang paling mudah ditemukan, $\mathrm{NaCl}$ sendiri merupakan salah satu bahan yang diperlukan dalam pembuatan sabun cuci piring karena garam atau $\mathrm{NaCl}$ berfungsi untuk mengentalkan hasil dari sabun cuci piring.

5. Foam Booster. Foam booster merupakan salah satu bahan kimia untuk penambah busa sabun. Oleh karena itu, bahan kimia yang satu ini juga menjadi salah satu bahan terpenting dalam pembuatan sabun. Foam booster ini berbentuk cairan kental dan memiliki sifat lembut di tangan. Selain itu, ia memiliki gelembung yang sifatnya sedang.

6. Essence Jeruk Nipis

7. Pewarna Makanan

Pelaksanaan kegiatan dari pengabdian masyarakat yang diadakan di Aula kantor Lurah Tangkerang Barat. Langkah awal dari kegiatan pengabdian masyarakat pelatihan pembuatan sabuns sebagai peluang wirausaha ibu-ibu rumah tangga di Kelurahan Tangkerang Barat yaitu penyampaian gagasan pelaksanaan pengabdian kepada pihak Kantor Lurah Tangkerang Barat. Pihak kantor lurah di lokasi pengabdian siap menerima kedatangan team pengadi dari UIN Suska Riau. Kegiatan pengabdian masyarakat dilaksanakan pada hari Rabu, tanggal 02 Oktober 2019. Kegiatan pengabdian dihadiri oleh 30 orang peserta yang terdiri dari Aggota PKK dan Majelis Taklim Kelurahan Tangkerang Barat. Para peserta pelatihan menunjukkan antusiasme yang sangat besar terhadap program pengabdian masyarakat yang diadakan Dosen UIN SUSKA Riau.

Materi pelatihan disampaikan oleh narasumber yang terdiri dari materi tentang bagaimana berwirausaha dan pembuatan sabun cuci piring. Kemampuan peserta pelatihan dalam penguasaan materi pelatihan pembuatan sabun cuci piring cukup baik karena para peserta sangat atusias dan banyak pertanyaan yang diajukan berkaitan dengan pembuatan sabun. Bahan-bahan untuk pembuatan sabun sudah disediakan tim pengabdian an hasil pembuatan sabun akan dibawa pulang oleh para peserta.

Di tahap awal kegiatan pengabdian masyarakat, peserta pelatihan diberikan pengetahuan tentang peluang wirausaha melalui pembuatan sabun. Tujuan tahap awal ini 
adalah ingin merubah pola pikir para peserta pelatihan bahwa pembuatan sabun cair (cuci piring) dapat menjadi peluang usaha karena memiliki peluang pasar.

Hasil kegiatan pengabdian secara garis besar dapat dilihat berdasarkan beberapa hal sebagai berikut:

1. Keberhasilan target jumlah peserta pelatihan

Keberhasilan target jumlah peserta pelatihan dapat dikatakan sangat baik. Target jumlah peserta pelatihan sebanyak 30 orang dan dalam pelaksanaan pengabdian dapat hadir sebanyak 30 orang. Hal ini didukung oleh pihak kelurahan dari persiapan, penyebaran undangan, penyediaan tempat kegiatan.

2. Pencapaian tujuan pelatihan

Pencapaian tujuan pelatihan dapat dikatakan baik Para peserta Pelatihan sudah dapat melakukan teknik pembuatan sabun dengan baik dan benar.

3. Pencapaian target materi yang telah direncanakan

Pencapaian target materi yang telah direncanakan dapat dikatakan baik. Semua materi pelatihan dapat disampaikan meskipun tidak secara detail karena keterbatasan waktu pengabdian. Materi pelatihan yang telah disampaikan adalah peluang wirausaha dan pembuatan sabun cuci piring.

4. Kemampuan peserta dalam penguasaan materi

Kemampuan peserta dalam penguasaan materi dapat dikatakan baik. Hal ini didukung dengan penggunaan metode ceramah dan demonstrasi untuk meningkatkan kemampuan peserta pelatihan dalam menyerap materi yang disampaikan oleh narasumber.

Secara keseluruhan kegiatan pelatihan pembuatan sabun cair dinilai berhasil. Keberhasilan ini selain diukur dari keempat komponen di atas, juga dapat dilihat dari kepuasan para peserta setelah mengikuti kegiatan. pelatihan dan selama kegiatan berlangsung tidak ada peserta yang pulang, para peserta mengikuti pelatihan kewirausahaan pembuatan sabun cuci piring sampai selesai.

Cara pembuatan sabun cuci piring yang diberikan kepada peserta pelatihan adalah:

1. Larutkan texapon didalam air sampai merata

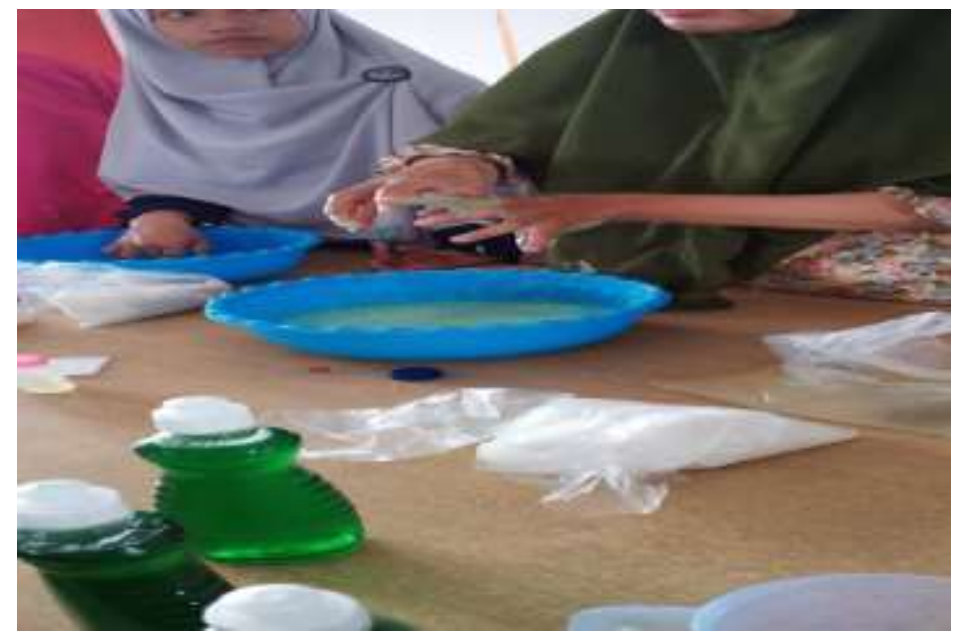

Gambar 1 Melarutkan Texapon di dalam Air Sampai Merata 
2. Larutkan sodium di dalam air

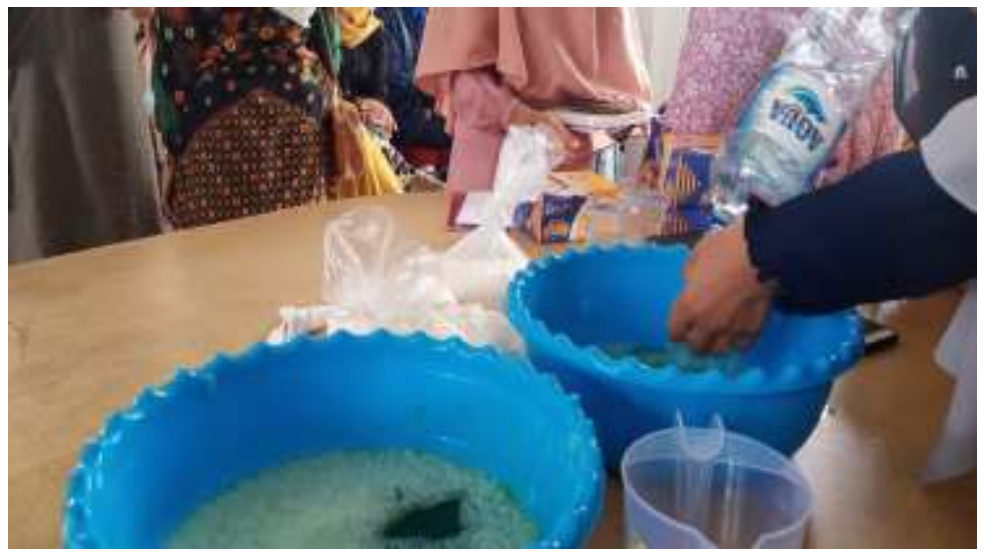

Gambar 2. Melarutkan Sodium di dalam Air

3. Campurkan texapon dan sodium

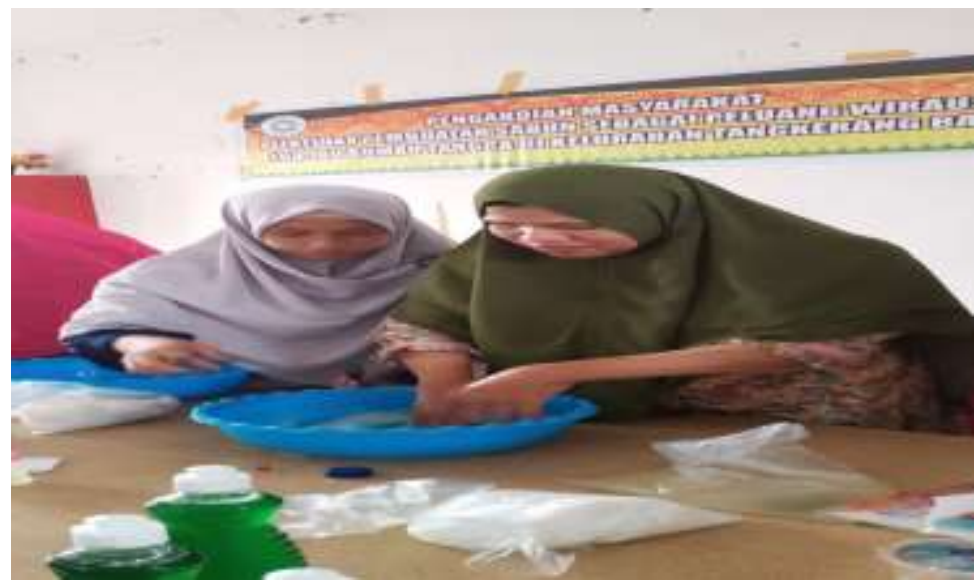

Gambar 3. Mencampurkan Texapon dan Sodium

4. Setelah texapon dan sodium dicampur, masukkan natrium chloride dan tambahkan essence, foam booster dan pewarna makanan

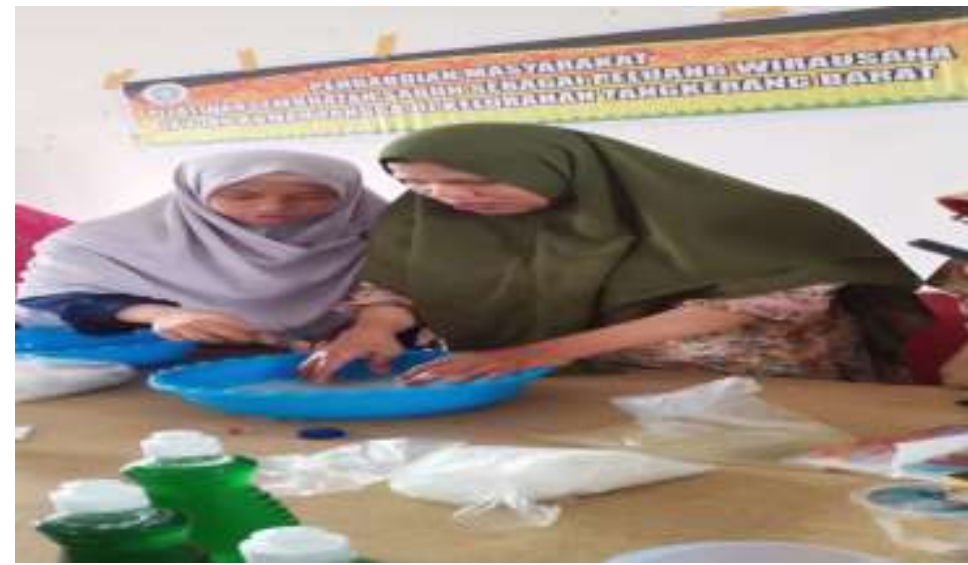

Gambar 4. masukkan natrium chloride dan tambahkan essence, foam booster dan pewarna makanan 
5. Setelah jadi sabun dimasukkan kedalam wadah dan di diamkan selama satu malam

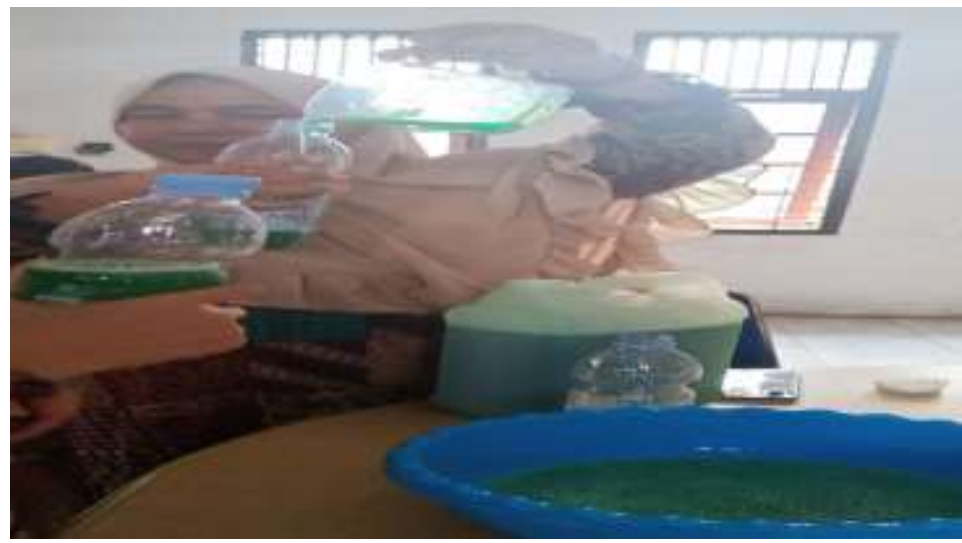

Gambar 5. Sabun Cair yang Siap untuk Dikemas

6. Pengemasan Produk Sabun Cair Cuci Piring

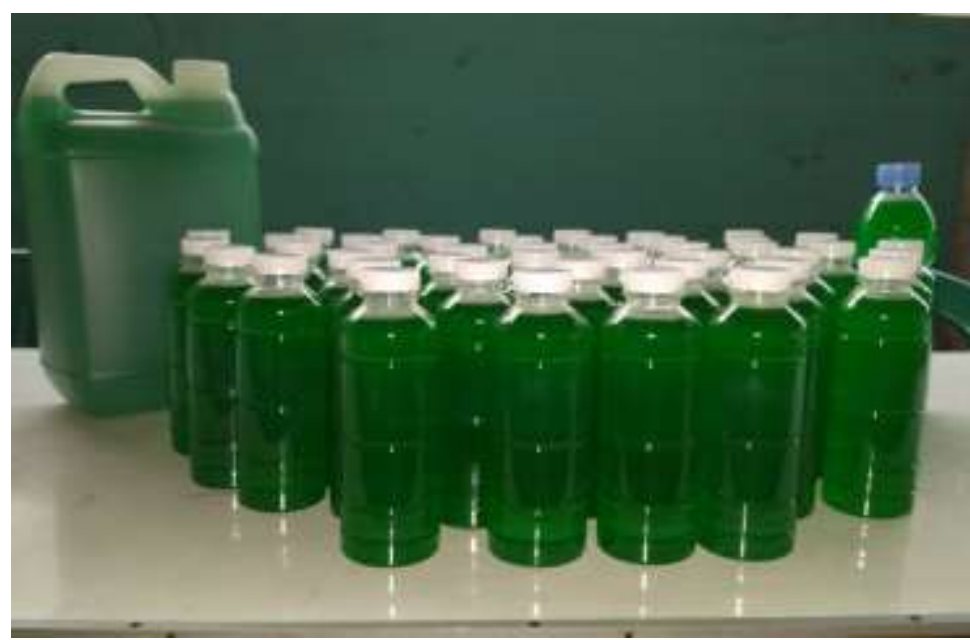

Gambar 6. Pengemasan Produk Sabun Cair Cuci Piring

Antusiasme peserta pelatihan semakin nampak dengan telah diberikan materi serta pembuatan sabun cair cuci piring.

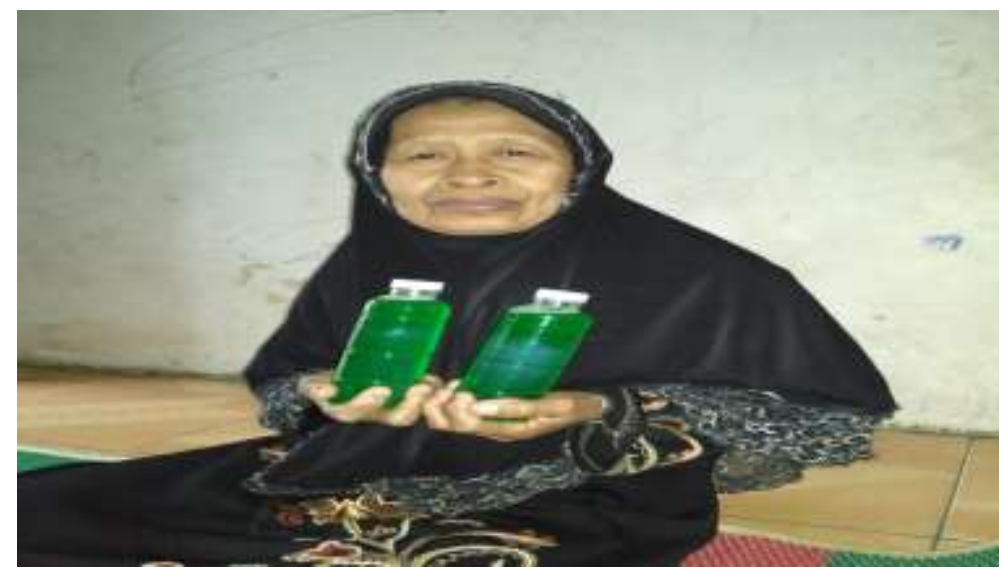

Gambar 7. Produk Sabun Cair Cuci Piring yang Dibuat Peserta Pelatihan 


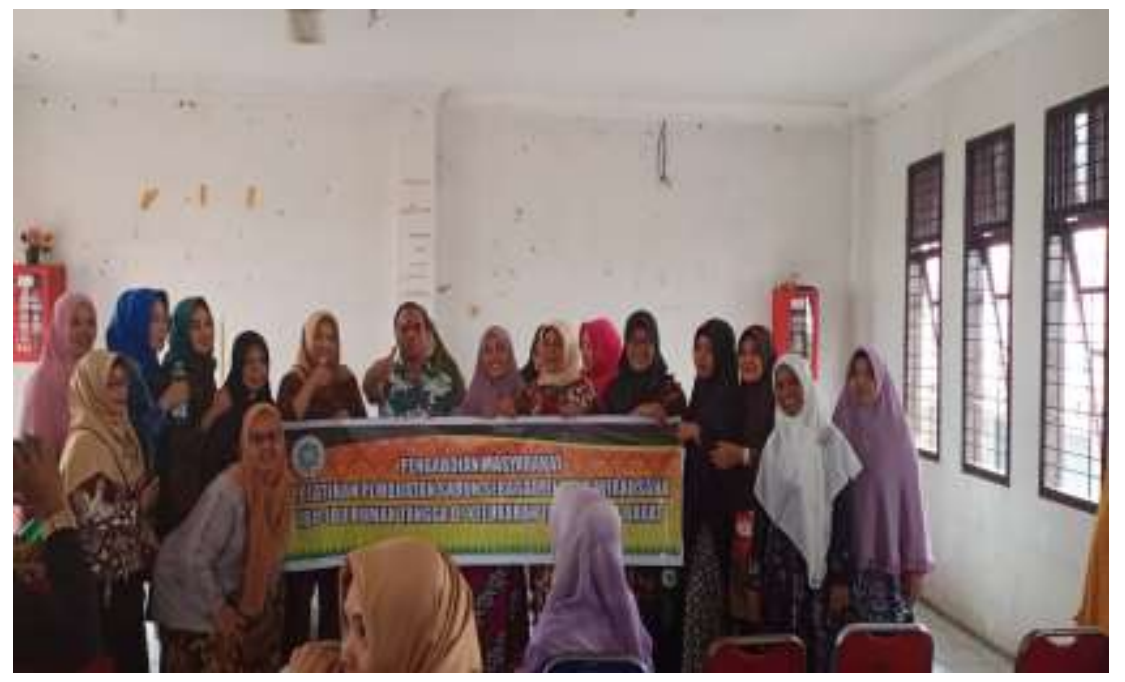

Gambar 8. Peserta Pelatihan Sabun Cair Cuci Piring di Kelurahan Tangkerang Barat Kota Pekanbaru

\section{KESIMPULAN}

Para perserta sudah menyadari akan peluang wirausaha pembuatan sabun cair cuci piring ramah lingkungan. Peserta pelatihan telah dapat mengembangkan sendiri pembuatan sabun cair cuci piring dan peserta pelatihan sudah ada yang berhasil menjual hasil produk sabun cuci piring mereka. Setelah berakhirnya kegiatan pengabdian masyarakat, peserta pelatihan saling berbagi ilmu dalam meningkatkan kreatifitas dalam pembuatan sabun cuci piring melalui arisan RT atau RW.

\section{DAFTAR PUSTAKA}

Hasibuan Malayu S.P., 2009, Manajemen Sumber Daya Manusia, Edisi Revisi, Jakarta: Bumi Aksara

Keller dan Kotler. 2012. Manajemen Pemasaran. Jilid I. Edisi ke 13. Jakarta: Erlangga.

Louw, A. \& Kimber, M. 2007. The Power of Packaging, The Customer Equity Company.

Moh Ali Aziz, dkk, 2005 Dakwah Pemberdayaan Masyarakat: Paradigma Aksi Metodologi, Yogyakarta: Pustaka Pesantren

Rangkuti, Freddy. 2010. Analisis SWOT: Teknik Membedah Kasus Bisnis. Jakarta: Gramedia. Simamora, Henry, 2004 , Manajemen Sumber Daya Manusia, Yogyakarta; STIE. YKPN.

Sulistiyani, Ambar Teguh. 2004. Kemitraan dan Model-Model Pemberdayaan. Yogyakarta: Gava Media

Suharto, Edi, 2005, Membangun Masyarakat Memberdayakan Rakyat, Bandung: Refika Aditama. 